\title{
Allogenic platelet-rich plasma in induced ulcers in rat's cornea
}

[Plasma rico em plaquetas alogênico em úlceras de córnea induzidas em ratos]

M.G. Gandolfi ${ }^{1}$, C.V.S. Brandão ${ }^{2 *}$, C.H. Pellizon ${ }^{3}$, I.N. Hirota ${ }^{1}$, R. Barros ${ }^{1}$,

A.C.B. Hussein ${ }^{1}$, N.B. Merlini ${ }^{1}$, R.K. Takahira ${ }^{2}$, L.R. Mesquita ${ }^{2}$

\author{
${ }^{1}$ Aluno de pós-graduação - Faculdade de Medicina Veterinária e Zootecnia - Universidade \\ Estadual Paulista - Botucatu, SP \\ ${ }^{2}$ Faculdade de Medicina Veterinária e Zootecnia - Universidade Estadual Paulista - Botucatu, SP \\ ${ }^{3}$ Instituto de Biociências - Universidade Estadual Paulista - Botucatu, SP
}

\begin{abstract}
The objective in this study was to evaluate the clinic effect of applying allogenic platelet-rich plasma (PRP) heated or not, for treating cornea ulcers, including the dosage of PDGF-BB in the cornea. The ulcers were induced, standardizing the left eye from 81 rats (Ratus norvegicus, albinus variety), assigned randomly into three groups $(\mathrm{N}=27)$ : control group $(\mathrm{CG})$ which did not receive any topic treatment; heated PRP group (GA) and PRP group (GP), which received topical treatment every eight hours for five days. Each group underwent evaluation at 24 hours (M1), three days (M3) and five days (M5). The clinical exam evaluated the opacity, vascularization and corneal repair. The corneal PDGF-BB was dosed through the ELISA method. The corneal opacity was decreased in PRP-treated animals (GA and GP) and corneal repair time reduced when compared to $\mathrm{CG}$ at M1 and M5. Furthermore, GP showed greater vascularization at M3 compared to M1. Applied allogenic PRP eye drops, heated or not, speed up corneal healing, and reduce corneal repair time. However, the corneal PDGF concentration was not altered in any of the treatments.
\end{abstract}

Keywords: heated platelet-rich plasma, growth factor, PDGF, plasma rich in growth factors, eye drops

\section{RESUMO}

Objetivou-se avaliar o efeito clínico da aplicação de plasma rico em plaquetas alogênico (PRP) aquecido ou não, no tratamento de úlceras de córnea, como a dosagem de PDGF-BB na córnea. As úlceras foram induzidas, padronizando-se o olho esquerdo de 81 ratos (Rattus norvegicus, variedade albinus), aleatoriamente, nos três grupos $(N=27)$ : grupo controle $(C G)$, que não recebeu nenhum tratamento tópico; grupo PRP aquecido (GA) e grupo PRP (GP), que receberam tratamento tópico a cada oito horas, durante cinco dias. Cada grupo foi subdividido em 24 horas (M1), três dias (M3) e cinco dias (M5). O exame clínico avaliou a opacidade, a vascularização e o reparo corneano. O PDGF-BB corneano foi dosado pelo método Elisa. Houve diminuição da opacidade da córnea nos animais tratados com PRP (GA e GP) e diminuição do tempo de reparo da córnea em comparação com CG, M1 e M5. Além disso, foi observada maior vascularização no GP no momento M3 em relação ao M1. A aplicação de colírios de PRP alogênico, aquecidos ou não, acelera a cicatrização da córnea, além de reduzir o tempo de reparo da córnea. No entanto, a concentração de PDGF na córnea não se alterou em nenhum dos tratamentos.

Palavras-chave: plasma rico em plaquetas aquecido, fator de crescimento, PDGF, plasma rico em fatores de crescimento, colirios

\section{INTRODUCTION}

Ulcerative keratitis is the most frequent ocular affliction in animals and occurs when the epithelium and a significant amount of the

Recebido em 10 de outubro de 2020

Aceito em 5 de abril de 2021

*Autor para correspondência (corresponding author)

E-mail:valeriasb@fmvz.unesp.br variable stroma is lost (Herrera, 2008). Due to the absence of vessels in the cornea, the cicatrization process is conducted by the inflammatory agents as well as the growth factors produced due to the injury (Gum and MacKay, 2013). The growth factors are produced 
by the epithelium, stroma and corneal endothelium (Zagon et al., 2000) and are present in tear film and aqueous humor that are constantly in contact with the cornea (Rolando and Zierhut, 2001; Long et al., 2007). In this context, these factors not only are extremely important in corneal repair due to the mending action in the proliferation of ephitelial cells and stromas, but also influence remodeling of the extracellular matrix (Scalinci et al., 2011).

Among the main growth factors in active corneal cicatrization is the platelet-derived growth factor (PDGF), which is necessary to modulate the proliferation, migration and differentiation of corneal and other cells (Singh et al., 2014). Studies that evaluated blood-based derivatives have shown that they are effective and safe in the treatment of many diseases of the ocular surface (Anitua, 2015). The derivatives found include platelet-rich plasma (PRP) characterized by high concentrations of platelets and growth factors, which are released by alpha granules from the platelets (Anitua et al., 2004). The use of PRP against ocular surface diseases has been often studied and applied. It is known that PRP has provided excellent results, accelerating the healing when applied in ophthalmology (Alió et al., 2007a, 2007b; Geremicca et al., 2010; Panda et al., 2012; Alió et al., 2013).

Anitua et al. (2014) evaluated the new PRP option, which is heated to $56^{\circ} \mathrm{C}$ for one hour after being prepared. In the previous study, it was verified that the concentrations of the majority of growth factors were not modified. However, the epidermal growth factor (EGF), proteins in the supplement system and immunoglobulin E ( IgE), presented significant decreases. It was concluded that the use of heated PRP is an option to treat ocular surface diseases in patients that have the autoimmune system as the basic etiology, since heating decreased the $\operatorname{IgE}$ levels and the supplemental system but maintained most of the proteins and other components involved in the cicatrization process. The author suggested in vivo studies to evaluate the efficiency and potential of the heated PRP.

Hypothetically, the use of growth factors originating from PRP in eye-drop form increases its presence in the cornea. Furthermore, the use of allogenic PRP, whether heated or not, originates from other animals of the same species and, in the eye-drop form, is able to accelerate healing as well as decrease the corneal opacity. In the consulted literature, no studies were found on the administration of heated PRP for treating corneal ulcers, or on the use of allogenic PRP, which has stimulated the development of this research. Therefore, we aim, in this study, to evaluate the clinical effect of the PRP and heated PRP, both allogenic, in the treatment of ulcers in the cornea, utilizing rats as experimental models. Furthermore, we seek to compare the response to the treatment with PRP and heated PRP, through the clinical evaluation and quantification of PDGF in the cornea, thus, establishing a new adjuvant therapeutic option in the healing of corneal ulcers.

\section{MATERIALS AND METHODS}

The developed experimental procedures followed the norms of the Association for Research in Vision and Ophthalmogogy (ARVO) and were approved by the Commission for Ethics in Animal Use from the Faculdade de Medicina Veterinaria e Zootecnia (FMCZ) - Campus of Botucatu, process number 92/2015-CEUA. The sample size was determined through a website: http://www.statstodo.com/index.php, but was recalculated using a significance level of 5\% and a test power of $80 \%$, thus determining the minimum sample number of nine animals per group, totaling 81 animals for the entire experiment. All of the 81 male and female rats (Ratus norvegicus, albinus variety) used were clinically healthy adults weighing from 200 to 300 grams and aged approximately 3 months. They were supplied by the central vivarium from Botucatu Campus-UNESP. They were also submitted to ophthalmologic examination by biomicroscopy in a slit lamp to exclude ophthalmic diseases.

The animals were kept in individual plastic cages during the experiment, identified at the vivarium of the Department of Surgery at FMVZ/UNESPBotucatu, under controlled temperature, light and humidity, receiving a diet composed of solid food and freely available water. For the collection and preparation of PRP, nine healthy rats were used. They were anesthetized using 
ketamine (Ketamine, ketamine hydrocloryde 50 $\mathrm{mg} / \mathrm{ml}$, Cristalida Prod. Quim. Farm. Ltda, Brazil) $(100 \mathrm{mg} / \mathrm{kg})$ associated with xylazine (Xylazine, xylazine hydrocloryde 2\%, Syntec, Brazil) $(10 \mathrm{mg} / \mathrm{kg})$, both intramuscular. After fifteen minutes, they were anesthetized with isoflurane via inhalation masks (Isoforine, isoflurane $100 \%$, Cristálida Prod. Quim. Farm. Ltda, Brazil), until achieving a total loss of pain and eyelid reflections.

Subsequently the blood was collected through intracardiac puncture, after which the animals were euthanized with an intracardiac injection of potassium chloride (Potassium chloride 10\%, Equiplex Ind. Farm Ltda, Brazil), resulting in 4.5 $\mathrm{ml}$ of blood per tube. The tubes were kept protected from light at ambient temperature for 30 minutes and next were centrifuged at $220 \mathrm{G}$ for ten minutes. Next, 1/3 of the supernatant was discarded and the remaining blood was transferred to $5 \mathrm{ml}$ sterile plastic tubes then centrifuged at $660 \mathrm{G}$ for ten minutes. The remaining $2 / 3$ was discarded from the supernatant, which was carefully homogenized (Merlini et al., 2014). To prepare the heated PRP after homogenization, it was kept in a double boiler at $56^{\circ} \mathrm{C}$ for 60 minutes (Anitua, 2014).

Both PRP samples were kept in $1 \mathrm{ml}$ tubes at a temperature between 2 and $4^{\circ} \mathrm{C}$, during the five days of treatment. The platelet development was quantified, in both simple and heated PRP, by the method of counting platelets in a Neubauer chamber, with results expressed as the number of platelets per $\mu 1$. To verify the alteration in the platelet development, the heated PRP was measured before and after the heating. All animals went under a surgical procedure to induce the corneal ulcer. They were anesthetized with ketamine (Ketamine, ketamine hydrocloryde 50mg/ml, Cristalida Prod. Quim. Farm. Ltda, Brazil) at the dosage of $100 \mathrm{mg} / \mathrm{kg}$, associated with xylazine (Xylazine, xylazine hydrocloryde 2\%, Syntec, Brazil) intramuscularly (IM) at the dosage of $10 \mathrm{mg} / \mathrm{kg}$. After 15 minutes, trichotomy was performed on the left chest region to enable vascular Doppler monitoring (Vascular Doppler, Parks Medical Electronics Inc., USA). The animals were maintained with isoflurane masks during the surgical procedure.
After instillation of an anesthetical eye drop (Anestalcon, hydrocloryde proximetacaine $0.5 \%$, Alcon, Brazil) to achieve total corneal desensitization, followed by ulcer demarcation by a puncture $3 \mathrm{~mm}$ in diameter and corneal delamination with a crescent-angled scalpel. For the unilateral procedure accomplished, the left ocular bulb was standardized, followed by induction of ulcers, instillation of diluted flourescein (fluoresceina strips, ophthalmos Ind. Co. Prod. Farm. Ltda, Brazil) and then photography. One dose of the analgesia with morphine was applied $(2 \mathrm{mg} / \mathrm{kg})$. Next, the animals were blindly and randomly distributed into three groups $(\mathrm{N}=27)$, in which the control group received no topical treatment $(\mathrm{CG})$; the plasma group was treated every eight hours with PRP eye drops (GP), and the heated PRP group comprised of animals treated with heated PRP eye drops every eight hours (GA).

The groups denominated CG, GP and GA were subdivided into other three groups $(\mathrm{N}=9)$, according to the time after the corneal ulcer induction, treated or not, and assessed at moment one (M1) - 24 hours after the surgical procedure; moment 3 (M3) - after three days; and moment five (M5) - after five days. All animals had an ophthalmic exam at each moment, after which they were euthanized. Each of the animals from the GA and GP groups received their respective treatments every eight hours until the maximum period of five days. The euthanasia was done simultaneously to the surgical procedure, so then the corneas were collected eight hours after the last PRP instillation - heated or not. The dosage was carried out in 81 corneas of rats, treated or not, distributed into the previously mentioned groups and subgroups. To collect the corneas, the same anesthetic protocol was applied to prepare the standardized PRP described above. After euthanasia, the left eye bulb was enucleated, followed immediately by total resection of the adjacent corneal limbus. The collected corneas were kept individually in a $1 \mathrm{ml}$ sterile tube and frozen at $-20^{\circ} \mathrm{C}$, following the manufacturer's instructions, until the dosage moment. The dose levels of growth factor PDGF-BB (mouse/rat PDGF-BB Quantikine ELISA Kit, Ink, USA), in $\mathrm{ng} / \mathrm{ml}$, were tested on corneas using the immunological ELISA test.

The clinic ophthalmic exam evaluated the opacity presence, vascularization and corneal 
repair, and was performed by a single hidden observer at the different observation moments. The corneal opacity level was classified based on a scale score from 0 to 4 , with 0 -indicating absence, cornea totally transparent; 1-mild, slight opacity traces, observed through oblique illumination; 2 - moderate, salient opacity, but not affecting viewing of the back chamber; 3 intense, impairing viewing of the back chamber; 4 - vivid, stroma total opacity, preventing backchamber viewing. A scale score from 0 to 3 was adopted for the vascularization, being: 0 absence, 1 - mild, 3 - intense. In addition, corneal repair was evaluated through photography and subsequently classified as: $0-$ absent, no corneal healing signals; 1 - partial; 2 total, complete healing. The statistical analysis for the PDGF-BB quantification was done through the technical variance analysis for a model with two factors, complemented by multiple comparisons of mean values by the Method of Tukey. The variables that did not present normal distribution - namely opacity, vascularization and corneal repair - were assessed by the nonparametric test for the model with two factors, complemented by Dunn's multiple comparisons (Zar, 2009), considering $0.5 \%$ as the significance level.

\section{RESULTS}

To obtain the PRP in rats, the double-spin protocol was applied. The procedure resulted in an average platelet development of 2,525,000 platelets per $\mu \mathrm{l}$ and a concentration 4.9 times greater than that in whole blood. But after heating the PRP at $56^{\circ} \mathrm{C}$ for one hour, the average platelet concentration was diminished from $2,525,000$ to 249,975 per $\mu 1$. No animals presented any type of adverse reaction after the instillation of allogenic PRP, heated or not, which suggests that despite originating from other individuals of the same species, there was not any rejection. In the evaluation of vascularization (Table 1), a significant increase was observed in the GP between M1 and M3 (P< 0.05). Greater corneal opacity (Table 2) was observed in CG both when compared to GA and GP $(\mathrm{P}<0.01)$ at $\mathrm{M} 1$, and when compared to GAheated $(<0.05)$ at M5. In all groups, a difference was observed between M1 and M5 (Table 3). The macroscopic aspect of the eye bulb is represented according to the different experimental groups in Figure 1. Corneal concentration of PDGF-BB is represented in Table 4.

Table 1. Corneal vascularization in the different evaluation groups and moments, represented by the average score followed by minimum and maximum values

\begin{tabular}{|c|c|c|c|c|}
\hline \multirow{2}{*}{ Group } & \multicolumn{3}{|c|}{ Evaluation Moment } & \multirow{2}{*}{$p$ Value } \\
\hline & M1 & M3 & M5 & \\
\hline $\mathrm{CG}$ & $0.0(0.0 ; 0.0)$ & $0.0(0.0 ; 3.0)$ & $0.0(0.0 ; 2.0)$ & $\mathrm{P}>0.05$ \\
\hline GA & $0.0(0.0 ; 2.0)$ & $0.0(0.0 ; 2.0)$ & $0.0(0.0 ; 2.0)$ & $\mathrm{P}>0.05$ \\
\hline GP & $\begin{array}{c}0.0(0.0 ; 0.0) \mathrm{A}^{*} \\
\mathrm{P}>0.05\end{array}$ & $\begin{array}{c}1.0(0.0 ; 1.0) \mathrm{B} \\
\mathrm{P}>0.05\end{array}$ & $\begin{array}{c}0.0(0.0 ; 1.0) \mathrm{AB} \\
\mathrm{P}>0.05\end{array}$ & $\mathrm{P}<0.05$ \\
\hline
\end{tabular}

Scores: 0-absence; 1-mild; 2-moderate; 3 -intense *Upper case: comparing moments $(\mathrm{P}<0.05)$ among the groups. CGcontrol group; GA-heated group; GP-PRP group.

Table 2. Corneal opacity in the different evaluation groups and moments, represented by average score, followed by minimum and maximum values

\begin{tabular}{lcccc}
\hline \multirow{2}{*}{ Group } & \multicolumn{3}{c}{ Evaluation Moment } & \multirow{2}{*}{$p$ Value } \\
\cline { 2 - 4 } & $\mathrm{M} 1$ & $\mathrm{M} 3$ & $\mathrm{M} 5$ & $\mathrm{P}<0.05$ \\
CG & $2.0(1.0 ; 2.0) \mathrm{b} \mathrm{B} *$ & $1.0(0.0 ; 3.0) \mathrm{AB}$ & $1.0(0.0 ; 2.0) \mathrm{b} \mathrm{A}$ & $\mathrm{P}>0.05$ \\
GA & $0.0(0.0 ; 1.0) \mathrm{a}^{* *}$ & $1.0(0.0 ; 1.0)$ & $0.0(0.0 ; 1.0) \mathrm{a}$ & $\mathrm{P}>0.05$ \\
GP & $0.0(0.0 ; 1.0) \mathrm{a}$ & $0.0(0.0 ; 1.0)$ & $0.0(0.0 ; 1.0) \mathrm{ab}$ & \\
$p$ Value & $\mathrm{P}<0.01$ & $\mathrm{P}>0.05$ & $\mathrm{P}<0.05$ & \\
\hline
\end{tabular}

Scores: 0-absence; 1-mild; 2-moderate; 3-intense; 4-intense *Upper case: comparing moments $(\mathrm{P}<0.05)$ among the groups. * Lower case comparing groups $(\mathrm{P}<0.05)$ set in time $\mathrm{CG}$-control group; GA-heated group; GP-PRP group. 
Table 3. Corneal repair in the different groups and moments, represented by the average scores, followed by minimum and maximum values

\begin{tabular}{lcccc}
\multirow{2}{*}{ Group } & \multicolumn{3}{c}{ Evaluation moment } & \multirow{2}{*}{$p$ Value } \\
\cline { 2 - 4 } CG & $0.0(0.0 ; 1.0) \mathrm{A} *$ & $0.0(0.0 ; 0.0) \mathrm{a} * * \mathrm{~A}$ & $1.0(1.0 ; 2.0) \mathrm{B}$ & $\mathrm{P}<0.01$ \\
GA & $0.0(0.0 ; 1.0) \mathrm{A}$ & $1.0(0.0 ; 2.0) \mathrm{b} \mathrm{AB}$ & $1.0(1.0 ; 2.0) \mathrm{B}$ & $\mathrm{P}<0.05$ \\
GP & $0.0(0.0 ; 1.0) \mathrm{A}$ & $1.0(0.0 ; 1.0) \mathrm{b} \mathrm{AB}$ & $1.0(1.0 ; 2.0) \mathrm{B}$ & $\mathrm{P}<0.05$ \\
& $\mathrm{P}>0.05$ & $\mathrm{P}<0.05$ & $\mathrm{P}>0.05$ & \\
\hline
\end{tabular}

Scores: 0-absence; 1-partial repair; 2-complete repair *Upper case: comparing moments $(\mathrm{P}<0.05)$ among the groups. ** Lower case: comparing groups $(\mathrm{P}<0.05)$ set in time $\mathrm{CG}$-control group; GA-heated group; GP-PRP group.

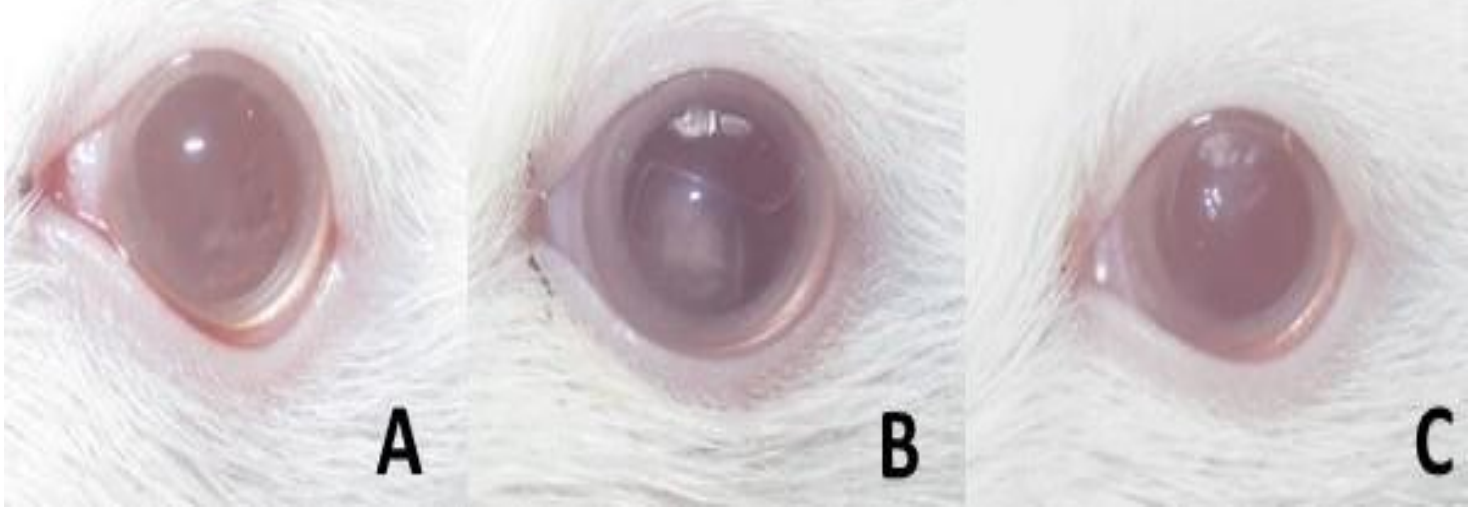

Figure 1. The macroscopic aspect from the ocular surface and enclosures in rats, after three days of treatment. Note: A and C. Mild opacity, absence of vessels and partial corneal repair in the heated group (GA) and PRP group (GP), respectively. B. intense opacity, absence of vessels and partial corneal repair in the control group (CG).

Table 4. Corneal concentration of PDGF-BB ( $\mathrm{ng} / \mathrm{ml})$ in groups at evaluation moments represented by mean and standard deviation

\begin{tabular}{lcccc}
\hline \multirow{2}{*}{ Group } & \multicolumn{3}{c}{ Evaluation moment } & \multirow{2}{*}{$p$ Value } \\
\cline { 2 - 4 } CG & M1 & M3 & M5 & \\
GA & $296.19(26.84)$ & $200.23(79.77)$ & $279.31(62.43)$ & $\mathrm{P}>0.05$ \\
GP & $272.31(141.78)$ & $233.10(39.31)$ & $251.99(103.33)$ & $\mathrm{P}>0.05$ \\
Value p & $274.20(79.43)$ & $148.58(21.92)$ & $251.76(69.98)$ & $\mathrm{P}>0.05$ \\
\hline
\end{tabular}

CG- control group; GA- heated group; GP- PRP group.

\section{DISCUSSION}

The applied protocol produced a good performance that achieved an efficient platelet concentration in rats. According to Marx et al. (2004), the concentration needed due to better efficiency in PRP use is four times the basal / baseline / initial concentration, that is, at least 500,000 to $1,000,000$ platelets per $\mu 1$. However, Alió et al. (2012) suggest an increase from 1.6 to 2.5 times. After the heating of PRP at $56^{\circ} \mathrm{C}$ for an hour, the average platelet concentration dropped from $2,535,000$ to 249,975 per $\mu$ l. Some areas with agregated platelets were also observed in the Neubauer chamber, which consequently resulted in a diminished concentration, since it is done based on the counting of isolated platelets. Therefore, the decrease was probably caused by the platelet aggregation.

However, Alió et al. (2013) proved that heated PRP maintains the concentrations of a variety of growth factors, due to their resistance to heating. On the other hand, these authors did not report platelet aggregation. The use of allogenic PRP was described by Lamplot et al. (2014), in a research study that evaluated the application of PRP on the cuff tendon of rats. In the consulted 
literature, this treatment on the ocular surface was not found. One of the main challenges related to the use of PRP, in humans or other species, is the necessity to collect a relatively significant amount of blood, in relation to the amount of PRP collected (Donatti et al., 2013 Espinosa et al., 2015). Thus, the utilization of allogenic PRP could be maximized. Additionally, PRP can be created and stocked for three months as described by Anitua et al. (2013), without quality loss.

Espinosa et al. (2015) have demonstrated the viability in the use of allogenic serum in human patients that require more serum. Additional studies are necessary to evaluate its safety, efficiency and the benefits. However, the use of autogenous, allogeneic and xenogeneic serum has already been well established in veterinary medicine (Jorge et al., 2003). However, especially in human medicine, disease transmission is an important factor to be considered in the use of allogenic PRP. Nevertheless, its heating has been studied in order to reduce the viral and microorganism load (Anitua et al., 2013). Ocular secretion was not found at any moment during the study, which suggests that the use of prophylactic antibiotic is not necessary in corneal ulcers in laboratory animals, given that they had been surgically induced and thus considered clean. This inference was corroborated by Donatti et al. (2013), who reported the use of antibiotic eye drops as unnecessary while treating ulcers surgically induced in rabbits with PRP eye drops.

In an experimental study on rabbits, Tandir et al. (2010) observed a delay in corneal epithelialization when PRP was applied in association with antibiotic, both via the subconjunctival route, in comparison with single subconjunctival PRP. Considering the above aspects, there was neither antibiotic use nor contamination in the current study. Thus, we could observe only the PRP action without medical interference. Evaluating vascularization in the GP group, a significant increase was noted between M1 and M3 $(\mathrm{P}<0.05)$, which can be due to growth factors in PRP, most notably among them vascular endothelial growth factor (VEGF), the main mediator during the corneal vascularization process. This current result was similar to that described by Perches et al. (2015), who reported greater vascularization in animals at the end of 30 days of topical PRP treatment and attributed this finding to the VEGF concentration in PRP.

Greater corneal opacity was observed in CG not only when compared to GA and GP $(\mathrm{P}<0.01)$ at M1, but also in relation to GA $(<0.05)$ at M5. This finding may be attributable to the growth factors present in PRP, which modulate the healing process, and diminish scar formation. Furthermore, Donatti et al. (2013) also observed less opacity in the groups treated with PRP after 30 days, correlated with the presence of available growth factor in PRP. It is known that platelet activation occurs when PRP, in the form of eye drops, enters into contact with the ocular surface and immediately releases a significant amount of growth factors (Alió et al., 2012). A significant difference was also verified between the GA group and $\mathrm{CG}$ at M5 $(\mathrm{P}<0.05)$ in contrast to GP versus $\mathrm{CG}$; indicating that the use of heated allogenic PRP decreases the opacity formation. This fact is attributable to the heating, a process that results in declining immunoglobulin $\mathrm{E}(\mathrm{IgE})$, as well as the complement system, although most of the growth factors persisted (Anitua, 2014).

In the $\mathrm{CG}$, as a consequence of its greater opacity, there was a significant decrease between the initial and final evaluation moments. However, at both moments the CG group mean was higher than those of the other groups. Considering the corneal repair, represented by the smallest corneal stroma depth in the ulcer region, we could observe in the M3 group better scar patterns in the GA and GP groups when compared with CG. Thus, it is suggested that PRP use accelerates corneal repair. In addition, at M3 only the treated groups displayed a tendency toward healing, compared to the initial moment M1. No animal presented ocular perforation. The faster repairing corroborates findings in literature, including Freire et al. (2014), who reported that active PRP use in vivo accelerates the healing time in induced ulcers in rabbits compared to autologous serum, and Donatti et al. (2013) who observed a buffer or amniotic membrane during the treatment with topical PRP in relation to non-topical PRP.

Furthermore, in two studies of humans, Geremicca et al. (2010) also observed a shortening of the healing time while treating PRP-refractory ulcers, as did Panda et al. (2012) 
in relation to chemical ulcers. There was no difference in PDGF-BB concentration among the groups or evaluated moments. Kaur et al. (2009) reported the presence of alpha receptors in the anterior stroma, which may have been provoked by the loss of free PDGF-BB, as they were attached due to stromal exposure caused by the corneal ulcer. The ELISA Method, applied in the present study, quantifies only the unattached PDGF-BB. Possibly, if the RNA expression had been assessed by the PCR method, greater detection of the influence of PRP use could have been observed in the treated groups. In addition, it is known that PDGF is commonly found in tears as well as in the cornea (Kim et al., 1999; Zhou et al., 2007). A low numerical concentration of PDGF-BB may be due not only to technical issues that impaired its measurement in a large portion of the tears, but also to the fact that the corneas were collected eight hours after the last PRP instillation, which can result in concentration loss, considering that the factors operate in the cornea and soon after are drained together with the tear drops.

Another possibility would be that the PDGF-BB is not the main isotope present on the rat cornea, or even the main growth factor functioning in the healing process, considering the presence of PDGF-AA, PDGF-AB, PDGF-BB (Penn et al., 2008), and the fact there are two more new members, PDGF-C and PDGF-D, which have protein structures similar to other isoforms (Betsholtz et al., 2001). Despite the absence of changes detected in the PDGF dosed, we could verify positive clinical results in the repairing process after the PRP treatment, heated or not.

\section{CONCLUSIONS}

The use of PRP does not alter the concentration of PDGF-BB levels; however, regardless of whether it is heated or not, its use is interesting considering the decrease in corneal opacity and acceleration of corneal healing. Considering the absence of adverse effects, allogenic PRP, heated or not, in eye-drop form, can be indicated as adjuvant treatment for corneal ulcers.

\section{ACKNOWLEDGMENTS}

This research was supported by CAPES (Coordenação de Aperfeiçoamento de Pessoal de Nível Superior). The authors wish to thank C. S. Perches and Ú. C. Guberman for all help.

\section{REFERENCES}

ALIÓ, J.L.; ABAD, M.; ARTOLA, A. et al. Use of autologous platelet-rich plasma in treatment of dormant corneal ulcers. Am. Acad. Ophthamol., v.114, p.1286-1293, 2007a.

ALIÓ, J.L.; ARNALICH-MONTIEL, F.; RODRIGUEZ, A.E. The role of "eye platelet rich plasma" (E-PRP) for wound healing in ophthalmology. Curr. Pharm. Biotech., v.13, p.1257-1265, 2012.

ALIÓ, J.L.; COLECHA, J.R.; PASTOR, S.; RODRIGUEZ, A.; ARTOLA, A. Symptomatic dry eye treatment with autologous platelet-rich plasma. Ophthamol. Res., v.39, p.124-129, 2007b.

ALIÓ, J.L.; RODRIGUEZ, A.E.; MARTINEZ, L.M.; RIO, A.L. Autologous fibrin membrane combined with solid platelet-rich plasma in the management of perforated corneal ulcers. J. Am. Med. Assoc. Formerly Arch. Ophthamol., v.131, p.745-751, 2013.

ANITUA, E.; ANDIA, I.; ARDANZA, B.; NURDEN, P.; NURDEN, A.T. Autologous platelets as a source of proteins for healing and tissue regeneration. Thromb. Haemost., v.91, p.4$15,2004$.

ANITUA, E.; MURUZABAL, F.; DE LA FUENTE, M.; MERAYO-LLOVES, J.; ORIVE, G. Effects of heat-treatment on plasma rich in growth factors-derived autologous eye drop. Exp. Eye Res., v.119, p.27-34, 2014.

ANITUA, E.; MURUZABAL, F.; PINO, A.; MERAYO-LLOVES, J.; ORIVE, G. Biological stability of plasma rich in growth factors eye drops after storage of 3 months. Cornea, v.32, p.1380-1386, 2013. 
ANITUA, E.; MURUZABAL, F.; TAYEBBA, A. et al. Autologous serum and plasma rich in growth factors in ophthalmology: preclinical and clinical studies. Acta Ophthamol., v.93, p.605614, 2015.

BETSHOLTZ, C.; KARISSON, L.; LINDAHL, P. Developmental roles of platelet-derived growth factors. Bioessays, v.23, p.494-507, 2001.

DONATTI, C.; BRANDÃO, C.V.S.; RANZANI, J.J.T. et al. Uso do plasma rico em plaquetas sob a forma de colírio ou tampão no reparo de úlceras de córnea profundas induzidas em coelhos: Avaliação clínica e histomorfométrica. Arq. Bras. Med. Vet. Zootec., v.65, p.809-818, 2013.

ESPINOSA, A.; HJORTH-HANSEN, H.; AASLY, K. et al. Implementation of a standardised method for the production of allogeneic serum eye drops from regular blood donors in a Norwegian University Hospital: some methodological aspects and clinical consideration. Transfus. Apheresis Sci., v.53, p.88-91, 2015.

FREIRE, V.; ANDOLLO, N.; ETXEBARRIA, J. et al. Corneal wound healing promoted by 3 blood derivatives: an in vitro and in vivo comparative study. Cornea, v.33, p.614-620, 2014.

GEREMICCA, W.; FONTE, C.; VECCHIO, S. Blood components for topical use in tissue regeneration: evaluation of corneal lesions treated with platelet lysate and considerations on repair mechanisms. Blood Transfus., v.8, p.107112, 2010.

GUM, G.G.; MACKAY, E.O. Physiology of the eye. In: GELLAT, K.N.; GILGER, B.C.; KERN, T.J. Veterinary ophthalmology. 5.ed. Iowa: Blackwell Publishing, 2013. p.171.207.

HERRERA, D. Afecções da córnea. In: Oftalmologia clínica em animais de companhia. São Paulo: MedVet, 2008. p.111.140.

JORGE, A.T.; CAMPOS, C.F.; TALIERI, I.C. et al. Topical effects of autogenous, allogenous and xenogenous blood serum on the healing of alkali burns in the cornea of dogs. Rev. Bras. Cienc. Vet., v.10, p.49-54, 2003.
KAUR, H.; CHAURASIA, S.S.; WILSON, S.E. Expression of PDGF receptor-alpha in corneal myofibroblasts in situ. Exp. Eye Res., v.39, p.432-436, 2009.

KIM, W. J.; MOHAN, R.R.; WILSON, S.E. Effect of PDGF, IL-1 alpha, and BMP2/4 on corneal fibroblast chemotaxis: expression of the plateletderived growth factor system in the cornea. Invest. Ophthamol. Vis. Sci., v.40, p.1364-1372, 1999.

LAMPLOT, J.D.; ANGELINE, M.; ANGELES, J. et al. Distinct effects of platelet-rich plasma and BMP13 on rotator cuff tendo injury healing in a rat model. Am. J. Sports Med., v.42, p.28772887, 2014.

LONG, Q.; CHU, R.; ZHOU, X. et al. Correlation between TGF- $\beta 1$ in tears and corneal haze following LASEK and Epi-LASIK. Am. J. Ophthamol., v.143, p.195-199, 2007.

MARX, R.E. Platelet-rich plasma: evidence to support its use. J. Oral Maxillofac. Surg., v.62, p.489-496, 2004.

MERLINI, N.B.; FONZAR, J.F.; PERCHES, C.S. et al. Uso de plasma rico em plaquetas em úlceras de córnea em cães. Arq. Bras. Med. Vet. Zootec., v.66, p.1742-1750, 2014.

PANDA, A.; JAIN, M.; VANATHI, M. et al. Topical autologous platelet-rich plasma eyedrops for acute corneal chemical injury. Cornea, v.31, p.989-993, 2012.

PENN, J. S.; MADAN, A.; CALDWELL, R. B. et al. Vascular endothelial growth factor in eye disease. Prog. Retinal Eye Res., v.27, p.331-371, 2008.

PERCHES, C.S.; PELLIZZON, C.H.; RANZANI, J.J.T. et al. Expressão de metaloproteinases de matriz e PCNA em úlceras de córnea profundas, induzidas em coelhos, tratadas com plasma rico em plaquetas. Arq. Bras. Med. Vet. Zootec., v.67, p.1607-1615, 2015.

ROLANDO, M.; ZIERHUT, M. The ocular surface and tear film and their dysfunction in dry eye disease. Surv. Ophthalmol., v.45, p.203-212, 2001. 
SCALINCI, S.Z.; SCOROLLI, L.; MEDURI, A. et al. Effect of basic fibroblast growth factor and cytochrome $c$ peroxidase combination in transgenic mice corneal epithelial healing process after excimer laser photoablation. $J$. Clin. Ophthalmol., v.5, p.215-221, 2011.

SINGH, V.; JAINI, R.; TORRICELLI, A.A.M. et al. TGFb and PDGF-B signaling blockade inhibits myofibroblast development from both bone marrow-derived and keratocyte-derived precursor cells in vivo. Exp. Eye Res., v.21, p.3540, 2014.

TANDIR, S.T.; YUKSEL, N.; ALTINTAS, O. et al. The effect of subconjunctival platelet-rich plasma on corneal ephithelial wound healing. Basic Invest., v.29, p.664-669, 2010.
ZAGON, I.S.; SASSANI, J.W.; MCLAUGHLIN, P.J. Reepithelization of the human cornea is regulated by endogenous opioids. Invest. Ophthalmol. Vis. Sci., v.41, p.73$81,2000$.

ZAR, J.H. Biostatistical analysis. 5.ed. New Jersey: Prentice-Hall, 2009.

ZHOU, L.; BEUERMAN, R.W.; HUANG, L. et al. Proteomic analysis of rabbit tear fluid: defensin levels after an experimental corneal wound are correlated to wound closure. Proteomics, v.7, p.3194-3206, 2007. 